\title{
PENINGKATAN SUMBER DAYA PANGAN ASAL HEWAN DI KECAMATAN KANDANGAN KABUPATEN KEDIRI
}

\section{IMPROVEMENT OF ANIMAL ORIGIN FOOD RESOURCES IN KANDANGAN KEDIRI}

\author{
Adiana Mutamsari Witaningrum ${ }^{1}$, Dhandy Koesoemo Wardhana ${ }^{2}$, Dian Ayu \\ Permatasari $^{3}$ \\ ${ }^{1,2,3}$ Departemen Kesehatan Masyarakat Veteriner, Fakultas Kedokteran Hewan, \\ Universitas Airlangga \\ e-mail: adiana.mw@fkh.unair.ac.id
}

\section{abstract}

Food of animal origin is used for human consumption such as meat, milk, eggs and the ir derivatives. Food safety for food of animal origin is needed to prevent biological, chemical and physical contamination that can interfere of human health. One of the animal-based food businesses that are mostly managed in the Kandangan, Kediri is milk. Activities carried out in this community service program are counselling and demonstrations related to increasing food resources of animal origin in the area. The community was able to understand this extension activity on the importance of increasing food resources of animal origin and was able to participate in demonstrations of making yogurt. The results of the pre-test and post-test on public knowledge and awareness of the evaluation of the delivery that have been given show an increase from an average of 89.1 points to 100 points. This activity is able to increase the know ledge and skills of the local community on how to increase animal-based food resources in order to develop the ir business.

Keywords : food, mastitis, milk, yogurt

\section{abstrak}

Pangan asal hewan dimanfaatkan untuk konsumsi manusia yang berupa daging, susu, telur dan hasil turunannya. Keamanan pangan pada pangan asal hewan diperlukan untuk mencegah cemaran biologis, kimia dan fisik yang dapat mengganggu kesehatan manusia. Salah satu usaha pangan asal hewan yang banyak dikelola di daerah Kecamatan Kandangan, Kabupaten Kediri yaitu susu. Kegiatan yang dilaksanakan dalam program pengabdian masyarakat ini berupa penyuluhan dan demonstrasi terkait peningkatan sumber daya pangan asal hewan di Kecamatan, Kabupaten Kediri. Masyarakat mampu memahami kegiatan penyuluhan ini akan pentingnya peningkatan sumber daya pangan asal hewan dan mampu mengikuti demonstrasi pembuatan yoghurt. Hasil pre-test dan post-test pada pengetahuan dan kesadaran masyarakat akan evaluasi dari penyampaian yang telah diberikan menunjukkan peningkatan dari rata-rata mendapatkan 89.1 poin menjadi 100 poin. Kegiatan ini mampu meningkatkan pengetahuan dan keterampilan masyarakat sekitar bagaimana cara meningkatkan sumber daya pangan asal hewan dalam rangka mengembangkan usahanya.

Kata kunci: mastitis, pangan, susu, yoghurt

\section{PENDAHULUAN}

Pangan asal hewan memiliki sifat yang mudah rusak dan berpotensi dapat membahayakan karena cemaran bahaya biologis, kimia dan fisik yang mengganggu kesehatan manusia (Peraturan Pemerintah No. 86, 2019). Susu merupakan salah satu pangan asal hewan yang memiliki kandungan gizi yang lengkap dan bermanfaat bagi kesehatan dan kecerdasan. Susu berasal dari ambing atau kelenjar susu ternak perah sehat dan bersih yang dilakukan dengan cara pemerahan yang benar (Permentan No. 26, 
Adiana Mutamsari Witaningrum, dkk.: Peningkatan Sumber Daya Pangan Asal Hewan Di Kecamatan Kandangan Kabupaten Kediri

2017). Berdasarkan data Kementerian Pertanian (2018), tingkat konsumsi susu nasional mencapai 11.8 liter/kapita/tahun pada tahun 2016. Produksi susu nasional tersedia $30 \%$ dari kebutuhan susu nasional. Hal ini mendorong upaya peningkatan produksi susu nasional melalui penanganan pengelolaan ternak dan pengolahan susu agar meningkatkan nilai jual dari susu tersebut sehingga dapat meningkatkan pendapatan para peternak.

Manajemen pengelolaan pada ternak yang tidak baik dapat menyebabkan adanya masalah kesehatan pada ternak. Mastitis merupakan salah satu masalah penyakit yang mengakibatkan kerugian pada peternakan sapi perah karena penurunan produksi susu, kualitas susu yang tidak baik, adanya biaya perawatan dan pengobatan hingga tindakan ternak di afkir. Mastitis adalah penyakit radang kelenjar ambing yang disebabkan oleh berbagai jenis bakteri (Balai Pengkajian Teknologi Pertanian Jawa Barat, 2017). Penyebab utama mastitis pada sapi adalah bakteri Streptococcus uberis, Streptococcus agalactiae, Streptococcus dysgalactiae, Staphylococcus aureus, Staphylococcus epidermis, Escherichia coli dan Klebsiella. Hal ini diperlukan adanya penanganan yaitu pemberian antibiotik dan pemeliharaan sanitasi kandang yang baik. Pengolahan hasil ternak berupa pangan asal hewan harus diperhatikan keamanan pangannya sebelum dipasarkan ke konsumen.

Pangan asal hewan harus mencakup standar ASUH yaitu aman, sehat, utuh dan halal. Hal ini dikarenakan pangan asal hewan memiliki sifat yang mudah rusak dan dapat membahayakan karena paparan cemaran biologi, kimia dan fisik. Pengolahan pada produksi pangan asal hewan khususnya susu dapat melalui proses pembuatan yoghurt yang dapat meningkatkan harga jual. Yoghurt merupakan produk olahan dari susu yang di fermentasi menggunakan bakteri asam laktat yang pada umumnya menggunakan $L$. bulgaricus dan S. thermophilus. Yoghurt dapat dikonsumsi oleh penderita lactose intolerance yaitu gejala malabsorbsi laktosa yang sering dialami oleh konsumen. Yoghurt juga dapat bermanfaat untuk penurunan kolesterol darah, menjaga kesehatan lambung dan pencegahan kanker saluran pencernaan. Hal ini merupakan peran dari bakteri yang digunakan dalam proses pembuatan fermentasi yoghurt (Ishmayana, 2015).

Kecamatan Kandangan merupakan kecamatan yang terletak di bagian Timur Laut dari pusat kota dari Kabupaten Kediri dengan jarak tempuh $\pm 33 \mathrm{Km}$ dan memiliki 12 desa, yang diantanya yaitu Medowo. Desa Medowo merupakan desa yang sebagaian besar masyarakatnya memiliki usaha peternakan sapi perah. Semakin banyak kebutuhan susu, maka peternakan sapi perah dan ind ustri susu semakin berkembang dari tahun ke tahun. Berdasarkan data jumlah sapi perah di wilayah Provinsi Jawa Timur sebesar 3.529.347. Wilayah di Jawa Timur yang merupakan sentra produksi sapi perah yaitu Surabaya, Malang, Pasuruan, dan khususnya daerah Kecamatan Kandangan, Kabupaten Kediri sebagai sentra peternakan sapi perah. Usaha peternakan sapi perah merupakan salah satu andalan sub-sektor peternakan di Kabupaten Kediri yang memiliki peluang prospektif dalam kegiatan agroind ustri sebagai salah satu sub-sistem agrobisnis. Sektor peternakan di Kecamatan Kandangan meliputi peternakan perorangan 513 orang, buruh usaha peternakan 422 orang, pemilik usaha peternakan 692 orang. Produksi Peternakan Tahun 2014 yang tercatat didalam data Dinas Peternakan Kabupaten Kediri menunjukan bahwa hasil produksi susu peternakan sapi perah yaitu sebanyak 12.172.927 liter. Hasil produksi susu perah dengan jumlah yang sebanyak itu tidak 
diimbangi dengan sanitasi kandang dan higiene peternak yang baik dari para peternak sapi di Kabupaten Kediri, hal ini disebabkan karena peternakan yang ada di Kabupaten Kediri utamanya di wilayah Kecamatan Kandangan masih menggunakan cara tradisional. Hal itu dapat mempengaruhi kualitas mikroorganisme dari susu sapi yang dihasilkan. Sehingga diperlukan penelitian dan pengabdian kepada masyarakat terkait identifikasi sanitasi kandang, higiene peternak serta kualitas fisik dan mikroorganisme susu sapi perah di wilayah tersebut (BPS, 2017).

\section{METODE PENGABDIAN MAS YARAKAT}

Pengabdian masyarakat ini dilaksanakan berdasarkan analisis hasil penelitian dan diskusi dengan warga masyarakat yang bertempat tinggal di Desa Medowo Kecamatan Kandangan Kabupaten Kediri Jawa Timur. Permasalahan yang sedang terjadi yaitu pengetahuan akan keamanan pangan asal hewan, pengolahan pangan asal hewan dan penanganan manajemen kesehatan ternak.

Solusi yang ditawarkan melalui program pengabdian masyarakat dari Lembaga Pengabdian dan Pengembangan Masyarakat (LPPM) dan Fakultas Kedokteran Hewan Universitas Airlangga yaitu penyuluhan dan demonstrasi penanganan dan pengolahan pangan asal hewan dengan baik.

Kegiatan pengabdian kepada masyarakat dilaksanakan pada tanggal 22 Agustus 2020 di Desa Medowo Kecamatan Kandangan Kabupaten Kediri Jawa Timur. Kegiatan ini dilaksanakan dalam beberapa tahap yaitu persiapan, pelaksanaan dan evaluasi. Pada tahap persiapan meliputi pembentukan panitia pelaksana kegiatan penyuluhan, pembuatan proposal, survey lokasi pelaksanaan kegiatan penyuluhan, melakukan proses perijinan ke lokasi kegiatan, membuat undangan tentang kegiatan penyuluhan kepada masyarakat setempat.

Pelaksanaan kegiatan dilaksanakan dari pukul 10.00 - 14.00 WIB, dengan susunan acara sebagai berikut: registrasi peserta, pembukaan, pretest peserta sebelum acara penyuluhan berlangsung, penyampaian materi tentang keamanan pangan asal hewan, mastitis dan pembuatan yoghurt oleh 3 pemateri, diskusi, posttest setelah kegiatan penyuluhan berlangsung dan penutup. Metode pelaksanaannya melalui penyuluhan dan demonstrasi. Monitoring dan evaluasi dikumpulkan dari lembar kehadiran peserta dan kemampuan masyarakat dalam mengikuti kegiatan. Observasi langsung pada saat penyuluhan dan demonstrasi dengan melihat interaksi antara peserta dengan pemateri penyuluhan dan keaktifan masyarakat dalam acara demonstrasi. Evaluasi dilakukan dengan menilai peningkatan pengetahuan atau demonstrasi melalui evaluasi pretest dan posttest terkait materi dan demonstrasi yang dilakukan. Peningkatan sumber daya pangan asal hewan dengan menerapkan hasil pengembangan ilmu pengetahuan dan teknologi. Pelaksanaannya dilakukan dengan penyuluhan dan pelatihan, sehingga masyarakat setempat dapat mengembangkan potensinya. Kegiatan dilaksanakan di Kecamatan Kandangan, Kabupaten Kediri. Kegiatan dilakukan menggunakan metode deskriptif analitis.

Tahap evaluasi yaitu pembuatan laporan hasil kegiatan pelatihan dan penyerahan laporan ke Lembaga Pengabdian Kepada Masyarakat. Evaluasi dilakukan untuk 
Adiana Mutamsari Witaningrum, dkk.: Peningkatan Sumber Daya Pangan Asal Hewan Di Kecamatan Kandangan Kabupaten Kediri

mengetahui respon peserta terhadap pelaksanaan kegiatan pengabdian ini. Evaluasi dilakukan terhadap tingkat pemahaman, partisipasi peserta dan keterampilan.

\section{HASIL DAN PEMBAHASAN}

Pengabdian kepada Masyarakat untuk meningkatkan sumber daya pangan asal hewan atas keamanan pangan asal hewan, penanganan pada mastitis dan pembuatan yoghurt guna peningkatan taraf hidup para peternak telah dilakukan oleh Tim Pengabdian Kepada Masyarakat Universitas Airlangga di Kecamatan Kandangan Kabupaten Kediri. Kegiatan diikuti oleh peternak dari Desa Medowo. Kegiatan yang dilakukan pada tanggal 22 Agustus 2020 pada pukul 10.00 WIB hingga 13.00 WIB berupa penyuluhan dan demonstrasi.

Kegiatan penyuluhan dilakukan dengan menggunakan metode pemaparan secara visualisasi dengan menggunakan LCD. Sebelum pelaksanaan penyuluhan, dilakukan pre-test terlebih dahulu untuk mengetahui sampai mana pengetahuan masyarakat di Desa Medowo Kecamatan Kandangan Kabupaten Kediri. Penyuluhan bertujuan untuk mengatasi permasalahan pada masyarakat setempat yaitu keamanan pangan asal hewan, penanganan mastitis dan pembuatan yoghurt dalam rangka menambah pengetahuan mengenai penanganan dan pengolahan pangan asal hewan.

Respon peserta terhadap kegiatan pengabdian masyarakat ini ditunjukkan dengan dilakukan evaluasi sebelum dan sesudah pelaksanaan kegiatan. Evaluasi dimaksudkan untuk mengetahui peningakatan pemahaman, partisipasi peserta dan keterampilan. Hal ini dilaksanakan dengan sebelum dan sesudah penyuluhan dilakukan pre-test dan posttest terhadap masyarakat Kecamatan Kandangan Kabupaten Kediri untuk mengetahui tingkat pemahaman setelah dilaksanakan penyuluhan terkait tentang keamanan pangan asal hewan, penanganan mastitis dan pengolahan produk susu dengan cara pembuatan yoghurt yang baik.

Berdasarkan hasil evaluasi pre-test dan post-test yang telah dilakukan sebelum dan sesudah dilaksanakan penyuluhan ternyata warga Desa Medowo Kecamatan Kandangan, Kabupaten Kediri yang memiliki usaha peternakan sapi perah mengalami peningkatan pemahaman mengenai kesehatan pangan asal hewan. Hasil ini ditunjukkan pada pre-test yang rata-rata mendapat nilai 89,1 . Setelah diadakan pelatihan post-test yang dilakukan mengalami peningkatan nilai menjadi rata-rata 100. Hasil kegiatan penyuluhan dan demonstrasi didapatkan bahwa peserta merasa puas dengan penyampaian materi dari narasumber dan demonstrasinya. Hal ini ditunjukkan dengan data hasil pretest dan posttest yang mengalami peningkatan, dan terlihat pada tabel 1.

Tabel 1. Distribusi Peningkatan Pengetahuan Masyarakat Peserta Penyuluhan tentang

Peningkatan Sumber Daya Pangan Asal Hewan dan demonstrasi di Kecamatan Kandangan

\begin{tabular}{lcc}
\hline Tingkat pengetahuan & Jumlah nilai & Rata-rata \\
\hline Pretest & 980 & 89.1 \\
Posttest & 1100 & 100 \\
\hline
\end{tabular}


Pemahaman warga Desa Medowo Kecamatan Kandangan Kabupaten Kediri mayoritas pada awalnya telah paham akan kesehatan pangan asal hewan dengan sangat baik dan setelah diadakan penyuluhan ada peningkatan pemahaman terhadap materi kesehatan pangan asal hewan.

Berdasarkan hasil pre-test, post-test, wawancara, dan pengamatan langsung selama kegiatan berlangsung, kegiatan pengabdian pada masyarakat ini memberikan hasil sebagai berikut: 1) Meningkatnya pengetahuan dan pemahaman masyarakat akan pentingnya keamanan pangan asal hewan. 2) Meningkatnya pengetahuan dan pemahaman masyarakat akan pentingnya kesehatan hewan yang baik. 3) Meningkatnya pengetahuan dan pemahaman masyarakat akan pentingnya pengolahan pangan asal hewan yang sehat dan baik.

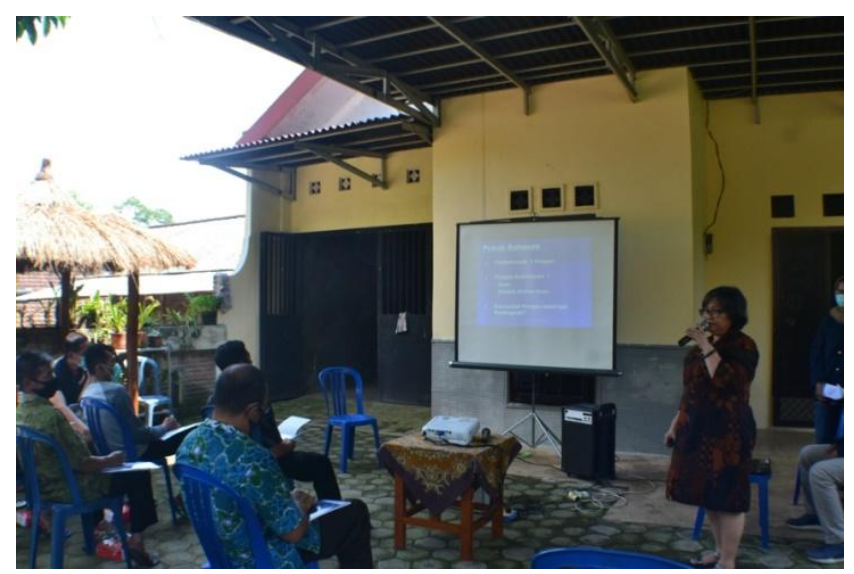

Gambar 1. Penyuluhan mengenai Kemanan Pangan Asal Hewan

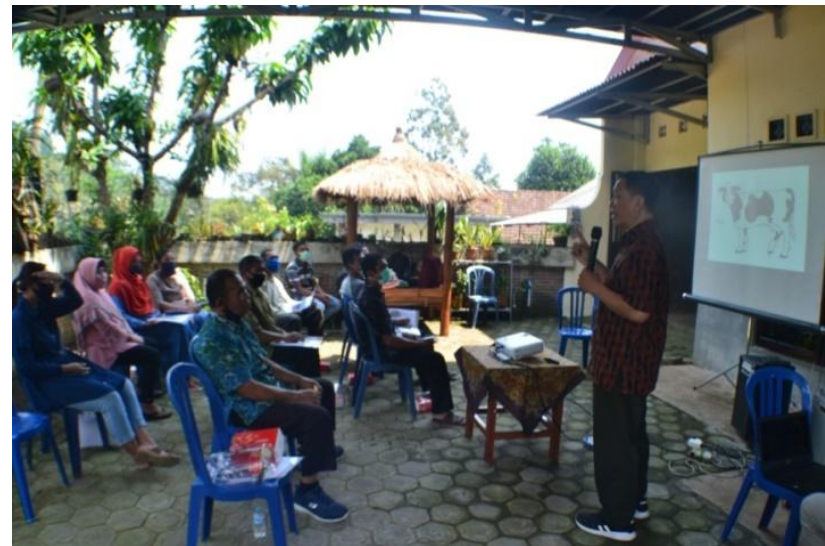

Gambar 2. Penyuluhan mengenai Mastitis pada ternak sapi perah 


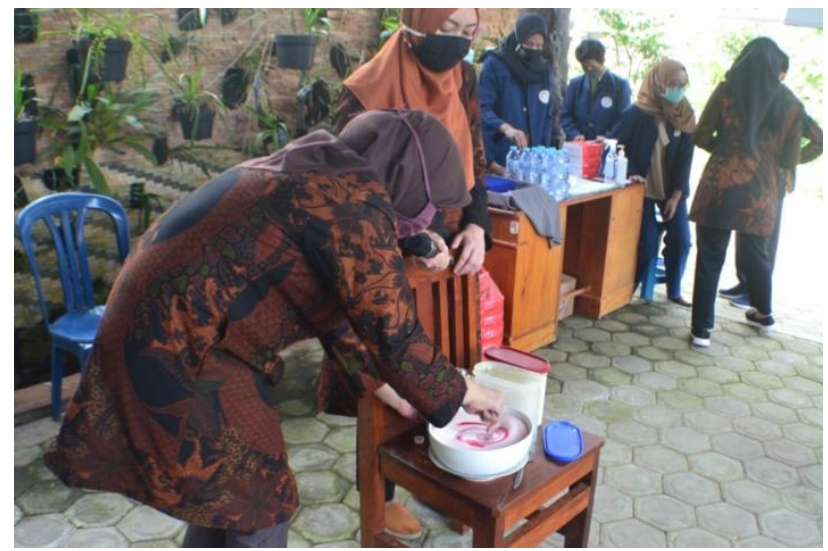

Gambar 3. Penyuluhan dan demonstrasi Pembuatan Yoghurt

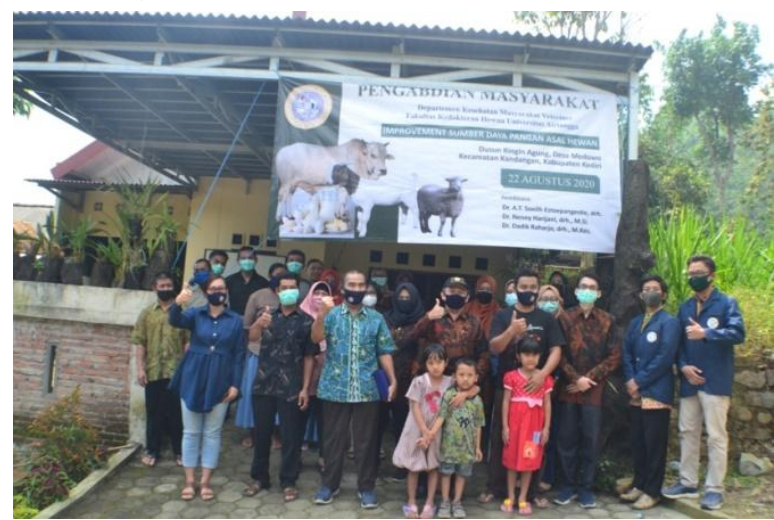

Gambar 4. Kegiatan Pengabdian Masyarakat Departemen Kesehatan Masyarakat Veteriner di Kecamatan Kandangan, Kabupaten Kediri

Pelaksanaan pengabdian masyarakat di Kecamatan Kandangan berjalan dengan baik dan lancar. Pengabdian ini ditujukan kepada masyarakat yang memiliki usaha peternakan sapi perah dengan metode ceramah yaitu dengan pemaparan materi yang dilakukan oleh para narasumber dan demonstrasi langsung, diharapkan dengan pengabdian masyarakat ini masyarakat memiliki penambahan wawasan dalam hal penanganan mastitis, memperhatikan keamanan pangan pada produk yang akan dihasilkan sehingga kualitas produk yang dihasilkan semakin terjamin untuk dikonsumsi oleh masyarakat dan para peternak mendapatkan tambahan wawasan mengenai peningkatan nilai jual susu dengan cara pengolahan susu melalui proses fermentasi menjadi yoghurt.

Materi-materi yang disampaikan dapat meningkatkan pengetahuan yang dibuktikan dengan respon dalam menjawab pertanyaan yang diberikan dengan baik dan benar. Masyarakat juga memperhatikan demonstrasi yang dilakukan pada kegiatan ini dan didukung dengan media video yang ditampilkan. Sehingga masyarakat dapat meningkatkan keamanan pangan asal hewan dengan memperhatikan bagaimana cara pengolahan, penyimpanan, pengemasan pada produk yang dihasilkan agar dapat dikonsumsi dengan layak oleh konsumen karena pangan merupakan kebutuhan dasar manusia yang paling hakiki yang harus dipenuhi setiap saat. Kualitas susu yang dihasilkan oleh ternak dipengaruhi oleh pakan, musim, masa laktasi dan penyakit. Kualitas susu segar di Indonesia sesuai dengan SNI 3141.1-2011. Masyarakat juga 
menambah wawasan mengenai manajemen pencegahan mastitis dengan menjaga kebersihan kandang, memanfaatkan kotoran menjadi biogas atau pupuk kendang dan melakukan dipping yaitu pencelupan ambing pasca memerah ke dalam larutan antiseptik serta memberikan antibiotik seperti penicillin, cephalosporin, sulfonamide, rifampin, clindamycin pada ternak yang terinfeksi kasus mastitis. Para peternak juga dapat meningkatkan nilai jual susu yang dihasilkan ternak dengan pengolahan susu yaitu susu segar yang telah mengalami perlakuan dengan tujuan memperpanjang daya simpan susu dan memperoleh produk susu bentuk, aroma dan rasa yang berbeda. Hal ini bertujuan untuk menyelamatkan produksi susu yang berlebihan, memperpanjang daya simpan susu, meningkatkan nilai ekonomi dari susu, mengoptimalkan susunan susu, dan memperoleh produk dengan aroma, bentuk dan rasa yang berbeda dengan susu segar. Pengolahan susu ini menggunakan mikroba yang menguntungkan dalam susu dan berfungsi sebagai pemberi aroma, mengentalkan dan membentuk konsistensi pada produk olahan, membentuk asam susu, menstimulasi kerja enzim serta menghambat pertumbuhan mikroba perusak produk. Produk olahan yang diperoleh dari susu yang dikentalkan dan dipasteurisasi kemudian ditambahkan starter (Lactobacillus bulgaricus, Streptococcus thermophillus, Bifidobacterium) melalui fermentasi sampai diperoleh keasaman, bau dan rasa yang khas dengan atau tanpa penambahan bahan yang lain. Syarat yang diguankan untuk bahan baku susu yaitu jumlah bakteri rendah, tidak mengandung enzim dan bahan kimia, tidak mengandung antimikroba dan bakteriofag, lemak berkisar antara 0,1\%-0,4\%. Proses pembuatannnya sangat mudah bagi masyarakat dengan memanaskan susu atau pasteurisasi susu, susu didinginkan dan ditambahkan starter yoghurt, produk dikemas pada wadah tertutup atau kedap udara dan menginkubasi pada suhu ruang selama 24 jam. Yoghurt yang telah jadi dapat bermanfaat untuk menurukan berat badan jika tidak ditambahkan pemanis, dapat dikonsumsi bagi penderita lactose intolerance dikarenakan laktosa dalam yoghurt telah diubah menjadi asam laktat dan kandungan enzim laktase yang berasal dari bakteri starter masih aktif serta bermanfaat sebagai probiotik.

Berdasarkan evaluasi pelaksanaannya dapat diidentifikasi faktor pendukung dan penghambat dari kegiatan ini sehingga dapat berjalan dengan baik dan lancar dengan dukungan Ketua KUD dan Kepala Desa. Sedangkan faktor penghambat dari kegiatan ini adalah pembatasan kegiatan dikarenakan adanya wabah Covid-19. Hasil dari penyuluhan dan demonstrasi pada masyarakat dapat diterapkan pada kegiatan seharihari pada usaha peternakan sapi perah para peternak.

\section{PENUTUP}

\section{Simpulan}

Pengabdian kepada Masyarakat ini memberikan pengetahuan pada peternak sapi perah dengan cara penyuluhan dan demonstrasi di Desa Medowo Kecamatan Kandangan mengenai pentingnya peningkatan sumber daya pangan asal hewan terutama pada keamanan pangan asal hewan, penanganan kasus mastitis dan pengolahan susu dengan metode pembauatan yoghurt. Dengan pelaksanaan kegiatan pengabdian masyarakat ini terjadi peningkatan pengetahuan akan sumber daya pangan asal hewan. Kenaikan nilai evaluasi pretest dan posttest menunjukkan bahwa pengetahuan masyarakat bertambah yang akan membantu para peternak meningkatkan produksi susu dan taraf hidup. Pengembangan akan kemampuan usaha para masyarakat dari Kecamatan Kandangan, Kabupaten Kediri masih diperlukan peningkatan untuk bidang yang lainnya. 
Adiana Mutamsari Witaningrum, dkk.: Peningkatan Sumber Daya Pangan Asal Hewan Di Kecamatan Kandangan Kabupaten Kediri

\section{Saran}

Pengabdian masyarakat untuk menggali peningkatan pemanfaatan sumber daya pangan asal hewan secara berkesinambungan sangat diperlukan untuk kemajuan usaha masyarakat Kecamatan Kandangan, Kediri khususnya dan seluruh wilayah Indonesia umumnya.

\section{Ucapan Terima Kasih}

Tim pengabdian kepada mas yarakat mengucapkan terima kasih atas bantuan pendanaan dari Keputusan Rektor Universitas Airlangga No 532/UN3/2020 Tanggal 1 Juli 2020 mengenai Pelaksanaan Program Pengabdian Masyarakat Universitas Airlangga Tahun 2020 sesuai dengan Surat Perjanjian Penugasan Pelaksanaan Pengabdian Kepada Masyarakat Universitas Airlangga Tahun Anggaran 2020 Nomor: 1698/UN3.1.6/PM/2020 Tanggal 2 Juli 2020. Tim pengabdian kepada masyarakat juga mengucapkan terima kasih kepada pimpinan institusi terkait atas bantuan kelancaran kegiatan pengabdian kepada masyarakat ini.

\section{DAFTAR PUSTAKA}

Amar, A., dkk. 2018. "Inkubator Produksi Yoghurt Skala Rumah Tangga untuk Perbaikan Proses Produksi di Kabupaten Kuningan.” Jurnal Mitra. Vol. 2 No. 2, November 2018: 80-91.

Badan Pusat Statistik. 2017. Kecamatan Kandangan Dalam Angka 2017. Kabupaten Kediri: Badan Pusat Statistik Kabupaten Kediri.

Balai Pengkajian Teknologi Pertanian Jawa Barat. 2017. Penyakit Mastitis Subklinis pada Sapi Perah. Badan Penelitian dan Pengembangan Kementerian Pertanian.

Fawaid, B. 2020. "Sanitasi Kandang, Higiene Peternak, serta Kualitas Fisik dan Mikroorganisme Susu Sapi Perah di Medowo, Kediri, Jawa Timur.” Jurnal Kesehatan Lingkungan. Vol. 12 No. 1 DOI: 10.20473/jk1.v12i1.2020.69-77 ISSN: 1829 - 7285 E-ISSN: 2040 - 881X.

Ishmamyana, S., dkk. 2015. "Pengaruh Konsumsi Yogurt yang Dibuat dengan Kultur Dua Bakteri (Streptococcus thermophilus dan Lactobacillus bulgaricus) dan Tiga Bakteri (Streptococcus thermophilus, Lactobacillus bulgaricus dan Lactobacillus acidophilus) terhadap Kadar Kolesterol Serum Darah Tikus." Chimica et Natura Acta. Vol. 3. No.3, Desember 2015:94-99.

Peraturan Menteri Pertanian. 2017. Penyediaan dan Peredaran Susu. Menteri Pertanian Republik Indonesia.

Peraturan Pemerintah. 2019. Keamanan Pangan. Presiden Republik Indonesia. 